\title{
Influence of Physical and Chemical Properties on Consumer Preference of Shredded Cabbage
}

\author{
Masamichi Yano*, Ryoyasu SAIJo**, Wataru SugaWARA*** \\ and Hideaki OHTA ${ }^{* * *}$ \\ * Okitsu Branch,Fruit Tree Research Station, Okitsunakacho, \\ Shimizu-shi, Shizuoka 424-02 \\ ** National Research Institute of Vegetables, Ornamental \\ Plants and Tea, Ano-cho, Age-gun, Mie 514-23 \\ ${ }^{* * *}$ Agricultural Technical Center, National Federation of \\ Agricultural Co-operative Associations, \\ 5-5-1, Higashihachiman, Hiratsuka-shi, Kanagawa 254 \\ **** Chugoku National Agricultural Experiment Station, 6-12-1, \\ Nishifukatsu-cho, Fukuyama-shi, Hiroshima 721
}

\begin{abstract}
To clarify desirable features of shredded cabbage, the relation between desirability according to a consumer panel and physical and chemical properties of the cabbage was investigated using 5 carefully selected cultivars. (1) The physical and chemical properties of the shredded samples having high desirability with respect to appearance, color, juiciness, firmness and taste are summarized as follows: small midrib size and thin mesophyll for appearance; high chlorophyll content and pale or light greenish yellow of inner leaves for color; high rate of dripping fluid from finely shredded samples under a fixed loading condition for juiciness; low puncture resistance of mesophyll for firmness; and low allyl isothiocyanate for taste. (2) Considerable juiciness, softness and good taste were the most important quality features for a high overall evaluation of shredded cabbage.
\end{abstract}

Shredded, ready-to-use vegetables are recently becoming popular in Japan due to the short time required for cooking and the absence of refuse thereafter. Damage to such vegetables is conspicuos and leads to a bad odor and browning. Considerable study has thus been conducted to devise ways to maintain good quality $^{1)-5)}$. Consumer preference is also an important factor to be considered, but no report has been made on this factor.

Cabbage, one of the main vegetables to be shredded, varies much in quality among cultivars, and thus the quality of the shredded product also varies ${ }^{6}$. . The quality of shredded cabbage is evaluated on the basis of appearance, color, juiciness, firmness and taste, and these 5 factors can be indicated by objectively measured values of the physical and chemical properties of material cabbage.
This study was made to clarify the physical and chemical conditions of shredded cabbage that would be preferred by most consumers. Using 5 carefully selected cultivars, desirability scores by a consumer panel and objective measures were determined for the 5 factors mentioned above and the relationships among them were investigated.

\section{Materials and Methods}

\section{Materials}

Five cultivars of cabbage greatly differing in quality were selected from the commercial cultivars reported in our previous study ${ }^{6)}$ on suitable cultivars for shredded cabbage. They were cultivated in the field of National Research Institute of Vegetables, Ornamental Plants and Tea in accordance with the usual commercial practice and harvested on June 
24 at prime market conditions of size and solidity.

Five heads from each cultivar were shredded $2 \mathrm{~mm}$ in width. Shredding allowed each cultivar to be a composite of all heads and represent all the morphological regions of a head. The samples were used for evaluating consumer preference and measuring physical and chemical properties. Other 5 heads were used for measuring some of these properties.

Measurment of physical and chemical properties

Midrib size was measured by weighing a midrib removed from the third leaf from the surface of the head. Thickness of the mesophyll was measured also at the third leaf with a dial calliper. Leaf color was assessed by comparing the color of the tenth leaf in the color chart for horticultural plants, published by the Japan Color Institute. Chlorophyll content was determined by the MACKINY method $^{7)}$. Puncture resistance of mesophyll was measured at the third leaf with an Instron type testing machine, and expressed as the force required to puncture the mesophyll with a $2 \mathrm{~mm}$ cylindrical plunger. The dripping rate was measured by weighing dripping fluid from finely shredded cabbage $(1 \times 1 \mathrm{~mm})$ under a fixed loading condition ( $15 \mathrm{~kg} / 15 \mathrm{~g}$ cabbage) for 3 minutes. Total sugar was extracted with $80 \%$ ethanol and determined using a Technicon Auto Analyzer ${ }^{8)}$. Allyl isothiocyanate (AITC) was determined by gaschromatographic analysis of flavor compounds in the juice from the shredded cabbage ${ }^{9)}$. The details of all of these procedures wer previously described ${ }^{10}$.

Evaluation of consumer preference
Eighy two staff members of the Vegetables and Ornamntal Crops Research Station, Sugino Women's College and Agricultural Cooperative Associations participated as consumer panelists. Shredded samples were presented to the panelists in random order on coded plates as soon as possible after preparation. They observed, chewed and tasted the samples, and were asked to rate the samples on a 3-point scale in regard to appearance (shape of shredded cabbage), color, juiciness, firmness, taste and overall impression. The 3-point scale was as follows : $2=$ more desirable than a reference cultivar, 'Koshinohikari' ; $1=$ almost equal to the reference ; $0=$ less desirable than the reference. Desirability was expressed as the mean of the panelists' scoring. 'Koshinohikari' had roughly intermediate characteristics of all the 5 factors among the 5 cultivars, as also noted in our previous report ${ }^{6)}$. Thus, it was selected as the most appropriate reference sample.

\section{Results and Discussion}

1. Desirability of 4 shredded samples evaluated by the consumer panel

Table 1 shows the desirability scores of 4 shredded samples with respect to appearance, color, firmness, juiciness and taste. In all cases, one or 2 samples out of 4 had rather high desirability scores and the other 1 or 2 samples, low scores. The results of analysis of variance in Table 1 show that there was significant difference in desirability for all 5 factors.

These results indicate that the shredded samples remarkably differed in quality as we had expected and the differences were percep-

Table 1 Desirability ratings of 4 shredded cabbage samples

\begin{tabular}{lccccc}
\hline \hline $\begin{array}{c}\text { Desirability } \\
\text { characteristics }\end{array}$ & Kosui & Greenball & $\begin{array}{c}\text { Fuyudori } \\
\text { miyako }\end{array}$ & $\begin{array}{c}\text { Akimaki } \\
\text { chuwase 2 }\end{array}$ & Probability \\
\hline Appearance & 1.24 & 1.38 & 0.41 & 0.56 & $<0.01$ \\
Color & 1.18 & 1.43 & 0.38 & 0.37 & $<0.01$ \\
Juiciness & 0.29 & 1.06 & 0.88 & 1.71 & $<0.01$ \\
Firmness & 0.35 & 1.13 & 0.88 & 1.40 & $<0.01$ \\
Taste & 0.63 & 0.98 & 0.81 & 1.18 & $<0.01$ \\
Overall & 0.42 & 1.07 & 0.55 & 1.14 & $<0.01$ \\
\hline
\end{tabular}


tible to the consumer panelists. Thus the 4 cultivars and reference were judged as suitable samples to investigate the relation between consumer preference and physical and chemical properties.

2. Relation between desirability and physical and chemical properties of shredded samples.

(1) Appearance and color

Shredded cabbage considerably varies in appearance (shape of shredded cabbage) among cultivars when prepared with a food processer for commercial use, and fine needle shaped samples containning no large pieces of mesophyll or midrib look good as shown in our previous report ${ }^{6)}$. Midrib size and thickness of mesophyll, apparently related to appearance, were measured for 4 cultivars and the reference. The values were compared with the desirability scores for appearance in Fig. 1. The relation between them was quite clear, cultivars with smaller midribs and thinner mesophyll had higher desirability scores. Although appearance is presently an unfamiliar quality for consumers, it might be important when shredded cabbage is commercialized, con-

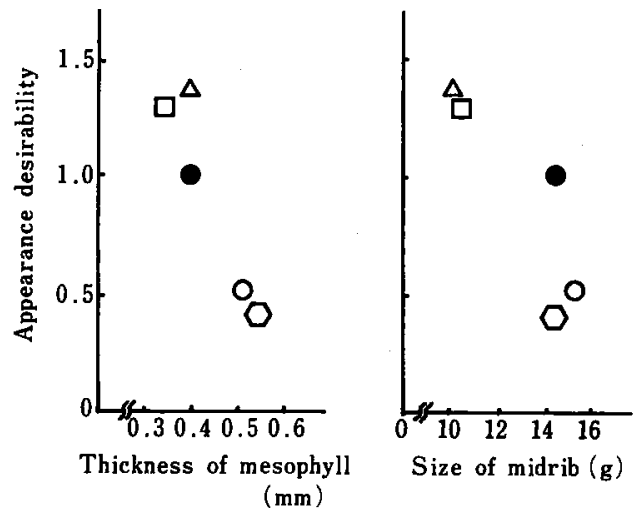

Fig. 1 Influence of thickness of mesophyll and size of midrib on the appearance desirability of 4 shredded cabbage samples

Triangles : 'Green ball' ; squares: 'Kosui'; hexagons: 'Fuyudori miyako' ; open circles : 'Akimaki chuwase 2'; closed circles : 'Koshinohikari' (control) sidering that desirability for appearance markedly varies with midrib size and thickness of mesophyll of material cabbage.

The relation between desirability for color and chlorophyll content and color name (code number) of material cabbage was investigated in the same way as for appearance (Fig. 2). Two greenish samples of high chlorophyll content, prepared from cultivars with inner leaves of pale greenish yellow or light greenish yellow (color code number 2702 or 2703), had high desirability scores. On the other hand, 2 yellowish white (2701) samples of low chlorophyll content had low desirability scores. It may thus be roughly concluded that greenish color is more desirable for shredded cabbage than white. We, however, should pay attention to the possibility that too intense green color causes consumers to doubt that shredded cabbage may be contaminated with outer, inedible leaves.

\section{(2) Texture (juiciness and firmness)}

The juiciness of shredded cabbage can be assessed from the amount of dripping fluid from finely shredded samples pressed under a fixed load. The dripping rate was determined as an indicator of juiciness, and compared with juiciness desirability in Fig. 3. The relation between them was quite clear. A shredded

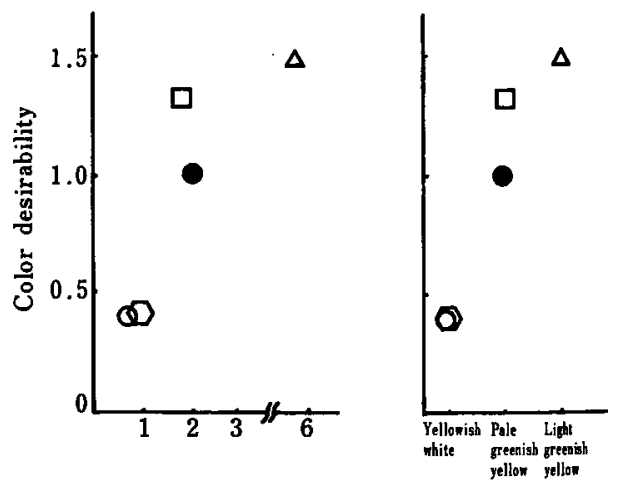

Chlorophyll (mg/100g f.w.) Color of inner leaves

Fig. 2 Influence of chlorophyll content and color of inner leaves on the color desirability of 4 shredded cabbage samples

Symbols are the same as those in Fig. 1. 


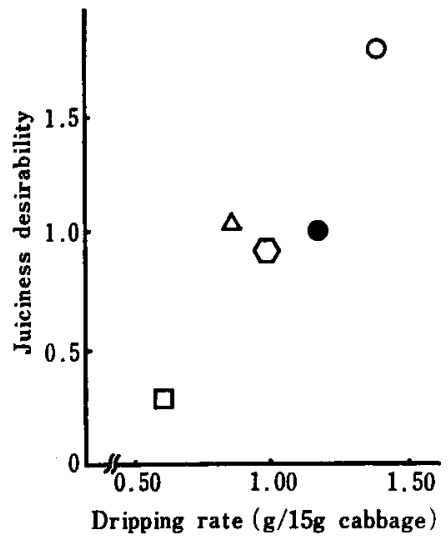

Fig. 3 Influence of dripping rate on the juiciness desirability of 4 shredded cabbage samples

Symbols are the same as those in Fig. 1.

sample with a high dripping rate had high desirability score, and other 2 samples with low dripping rate, low desirability scores. Thus a high dripping rate may be a quality making of shredded cabbage favorable to consumers.

The puncture resistance of mesophyll by which firmness of shredded cabbage can be estimated, was measured by an Instron type instrument and its relation to firmness desirability was illustrated in Fig. 4. Two shredded samples from cultivars of low puncture resistance, meaning soft cabbage, had high scores of firmness desirability, and another sample of high puncture resistance, a low score. However, one sample ('Kosui') had by far the lowest desirability, in spite of intermediate puncture resistance, indicating not so firm. Since 'Kosui' is markedly less juicy (Fig. 3), such shredded cabbage may be rated low even for firmness by consumers probably due to the feeling in the mouth when chewed.

Thus, both low puncture resistance and high dripping rate are essential for shredded cabbage to be considered favorable for good texture by consumers.

(3) Taste

Cabbage taste depends on the presence of certain chemical constituents, such as sugars and pungent and bitter substances. We deter-

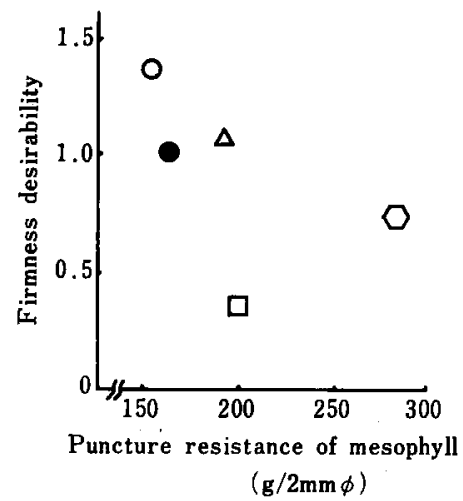

Fig. 4 Influence of puncture resistance of mesophyll on the firmness desirability of 4 shredded cabbage samples

Symbols are the same as those in Fig. 1.
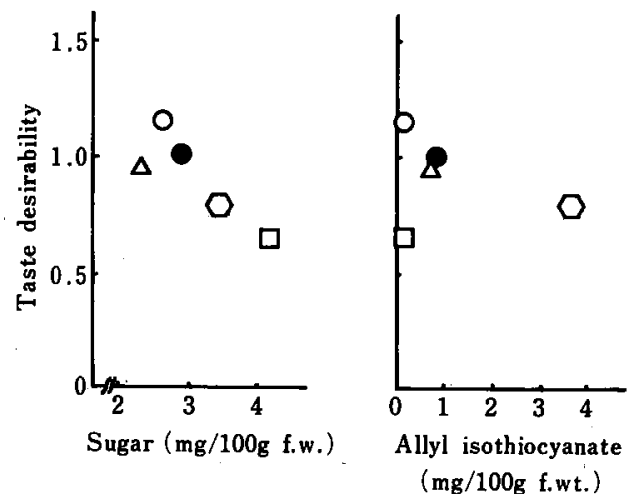

Fig. 5 Influence of sugar and allyl isothiocyanate contents on the taste desirability of 4 shredded cabbage samples

Symbols are the same as those in Fig. 1.

mined total sugar and ally isothiocyanate, a pungent constituent, sine these components have been studied in detail in relation to cabbage taste ${ }^{9) 11}$. The values are compared with taste desirability. in Fig. 5. Differing from the 4 factors above, there was no apparent correlation between the 2 substances and taste desirability. Two samples of high sugar content, contrary to our expectation, had rather low desirability scores ('Fuyudori miyako' and 'Kosui'). But this does not necessarily mean that high sugar content is not essential for good taste. In the case of these 
two cultivars, their high sugar content may have been concealed by poor texture (firm or less juicy). Another sample ("Akimaki chuwase 2') rated relatively high, on the contrary, may have low sugar content but high juiciness.

As for allyl isothiocyanate (AITC), the finding that 'Akimaki chuwase 2' of the lowest AITC content had the highest desirability score, 'Fuyudori miyako' with the highest AITC content and lower score was observed as shown in Fig. 5. This finding shows higher AITC content is unfavorable factor for good taste, probably because of its pungency. 'Kosui' with the lowest AITC content but with low score suggests the existence of another unfavorable factor, and we are suspicious about a lack of juiciness as the factor.

Low AITC content and high juiciness thus appear to be more important factors for good taste than sugar content.

\section{Overall evaluation}

The overall desirability of the 4 shredded samples compared to the reference was assessed by the same method as for the 5 factors above (Table 1). Two samples ('Akimaki chuwase 2' and 'Green ball') out of 4 had relatively high scores, and the 2 other samples ('Kosui' and 'Fuyudori miyako'), low scores. By comparing the quality features of the former samples with those of the latter, the quality features preferred by the most consumers can be determined.

'Akimaki chuwase 2', rated highest by the paneslists, had distinctive features such as high juiciness, and good taste, as evident from 1.71 and 1.18 , their respective desirability scores (Table 1). 'Kosui' and 'Fuyudori miyako' rated low had the exacti opposite features of 'Akimaki chuwase 2', a lack of juiciness and unfavourable taste, as also evident from their scores in Table 1.

These differences in quality features among the cultivars appear to provide basis for concluding that high juiciness, softness and good taste are necessary conditions for shredded cabbage to be preferred by most consumers. Other features, such as good appearance and greenish color are important but without high juiciness and good taste, do not contribute to favorable evaluation. This has clearly been demonstrated by 'Kosui' which had high desirability scores for appearance and color and a low score for juiciness and thus a low score for its overall evaluation.

\section{References}

1) Kawano, S., Onodera, T., Hayakawa, A., Kawashima, K. and Iwamoto, M.: Rep. Natl. Food Res. Inst., No. 45, 86 (1984).

2) Yano, M. and SaIJo, R.: J. Jpn. Soc. Cold Preserv. Food, 13, 11 (1987).

3) Ohta, H. and Sugawara, W.: J. Jpn. Soc. Food Sci. Technol., 34, 432 (1987).

4) Nawa, Y., Hosoda, H., Shina, T., IтoH, Y. and Kurogi, M. : Rep. Natl. Food Res. Inst., No. 50, 56 (1987).

5) Sugawara, W., Kawano, S., Shinna, T. and OHTA, H. : J. Jpn. Soc. Cold Preserv. Food, 13, 92 (1987).

6) Yano, M., Obama, S. and Saijo, R. : Bull. Veg. Ornam. Crops Res. Stn., A 14, 103 (1986).

7) Mackinney, G.: J. Biol. Chem., 140, 315 (1941).

8) Technicon Original Ind. Method 289-73 W.

9) YaNo, M., Itoh, H. and SAIJo, R. : J. Jpn. Soc. Food Sci. Technol., 34, 608 (1987).

10) Yano, M., Obama, S. and SaIjo, R. : Bull. Veg. Ornam. Crops Res. Stn., A 14, 119 (1986).

11) Takahashi, K. : J. Jpn. Soc. Hortic. Sci., 39, 318 (1970).

(Received Jun. 30, 1989)

\section{カットキャベッの消費者噫好に対する} 理化学的性質の影整

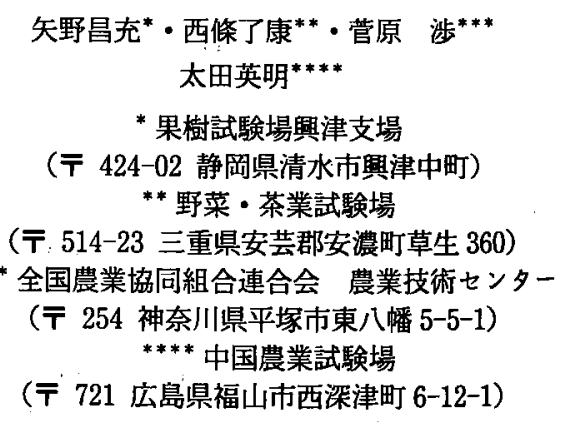

（テ 721 広島県福山市西樑津町 6-12-1）

消費者に好まれるカットキャベッの特徵を明らかにす 
るため，消費者パネルが判定した譛好の程度と理化学的 性質の関係を特に選んだ 5 品種を用いて調べた。

（1）外観，色，多汁性，硬さ，食味の 5 種類の性質そ れぞれについて，パネルが好ましいと判定したカットキ ヤベッの理化学的性質は次のとおりであった：外観，中 ろくが小さいこと及び葉肉が薄いこと；色，クロロフィ ルが多いこと，結球内部葉が淡緑黄または浅緑黄である
こと; 多汁性，試料に一定の荷重をかけた時のドリッ ブ率が大きいこと；硬さ，葉肉の貫入抵抗が小さいこ と；食味，アリルイソチオシアネート含量が少ないこと．

(2) 総合評価では, 多汁性であること，軟らかいこと 及び優れた食味がカットキャベッが消費者に高い評価を 受けるための最も重要な要因であった。 